\title{
STUDIES ON FUNCTIONAL BACTERIA OF INDONESIAN TROPICAL FOREST PLANTS FOR BIOREHABILITATION OF DEGRADED LANDS ${ }^{1}$
}

\author{
Irnayuli R. Sitepu ${ }^{2,3}$, Yasuyuki Hashidoko ${ }^{4}$, Aryanto², Maman Turjaman², Satoshi
} Tahara $^{3}$, Siti S. Miftahuliyah ${ }^{5}$, and Erdy Santoso ${ }^{2}$

\begin{abstract}
Forest degradations have left vast amount of damaged and abandoned lands in Indonesia. In this paper, we present our approaches in rehabilitation of adverse soils using functional bacteria isolated from plant species of Indonesian tropical rain forests. For these purposes, we collected bacteria from various bio-geo-climatically different forests and conducted bioassays to test these bacterial abilities in improving plant growth. Repeated seedling-based studies on Shorea spp., Alstonia scholaris, Acacia crassicarpa, and Agathis lorantifolia have revealed that many bacteria were able to promote plant growth at early stage in the nursery. Various plant responses towards inoculations suggested that although forest soils maintain highly diverse and potent bacteria, it is necessary to select appropriate approaches to obtain optimum benefits from these plant-bacteria interactions. Our ideas and futures studies for further management of these plantbacteria interactions for biorehabilitation are also discussed.
\end{abstract}

Keywords: Plant-bacteria interaction, growth promotion, adverse soil

\section{INTRODUCTION}

Recurrence of massive forest fire, illegal logging, mining, and mismanaged activities conducted individually or institutionally have led to vast amounts of destroyed and converted forest areas worldwide. Indonesian forests have been exploited for more than 20 years now, resulting in more than 20 million hectares of deforested areas (Subiakto et al., 2005). Stressed/adverse soils are often associated with nutrient limitation, and extremely low $\mathrm{pH}$ condition is associated with high Al concentration in the soil solution. Tilak et al. (2005) reported only $1 \%$ of the total $\mathrm{P}$ present in the soil is available to plants due to

\footnotetext{
1 Paper presented in International Workshop on Rhizosphere Technology in Sustaining Plan Growth in Adverse Soils and Prediction for Carbon Trade, Banjarmasin, Indonesia, 25-26 February 2008.

2 Forest Microbiology Laboratory, Forest and Nature Conservation Research and Development Center, Jalan Gunung Batu No. 5, P.O. Box 165, Bogor 16610, Indonesia.

3 Corresponding author. E-mails: irnars@hotmail.com; irnayuli@forda-mof.org

4 Ecological Chemistry Laboratory, Division of Applied Bioscience, Graduate School of Agriculture, Hokkaido University, Kita-9, Nishi-9, Kita-Ku, Sapporo 060-8589, Japan.

5 Forestry Faculty, Winayamukti University, Jatinangor, Indonesia.
} 
its chemical bonding and low solubility. These complex problems as well as a severe leaching on the forest floor, and/or presence of toxic elements have caused low survival rate of transplanted seedlings into these adverse areas. Thus, rehabilitation on such degraded, abandoned, and adverse lands remains a trivial effort.

Attempts to improve soil condition such as that applied in agricultural sectors by adding inorganic fertilizer and lime to increase the soil $\mathrm{pH}$ are inefficient and can pollute the environments because forests usually cover considerably vast areas that include mountains, rivers, and villages. Albeit rehabilitation efforts have been recently intensified and accelerated to encounter the global issue of the human impact towards the environment, these actions seem suffer draw back and become less effective without a proper identification and solution to the real problems.

Rising reports on the beneficial effects of functional bacteria on plant growth have inspired many researchers to understand this host-bacteria interaction. In subtropical regions, applications of plant growth-promoting rhizobacteria (PGPR) for improving seedling growth in the nursery for forest management have been increasing (Chanway, 1997; Garcia et al., 2004). However, investigations on functional bacteria from Indonesian forests have not been adequately studied. Bacteria play a pivotal role in maintaining nutrient cycle, preserving nutrient for plant growth, and improving soil structure and fertility (Lucy et al., 2004).

In this paper, we discuss our approach in utilizing rhizobacteria for plant growth promotion. Rhizobacteria were collected from various forest conditions and plant species in Indonesia and tested for growth promotion on Acacia crassicarpa, Shorea selanica, Shorea leprosula, Agathis lorantifolia, and Alstonia scholaris in the nursery.

\section{MATERIALS AND METHODS}

\section{A. Isolation and Screening Strategy}

Roots are an important reservoir for bacteria. Root/rhizosphere is a "hot zone" where active nutrient circulation takes place. In our study, most bacteria were isolated from root (or nodules) and soils of the host plants. We used culture-based method in isolations of bacteria with various media that are based on our interests: (1) for trapping oligotroph: yeast mannitol agar, and Winogradsky's mineral mixture-based nitrogen-free medium solidified with 0.3\% gellan gum (WMM; Hashidoko et al., 2002); (2) for trapping auxotroph: nutrient agar, and potato dextrose agar. The use of WMM not only allowed the emergence of epiphytes but also endophytic bacteria. 
The orderly strategy for studying functional bacteria for plant growth promotion generally follows illustration in Figure 1. References therein describe the methods in detail.

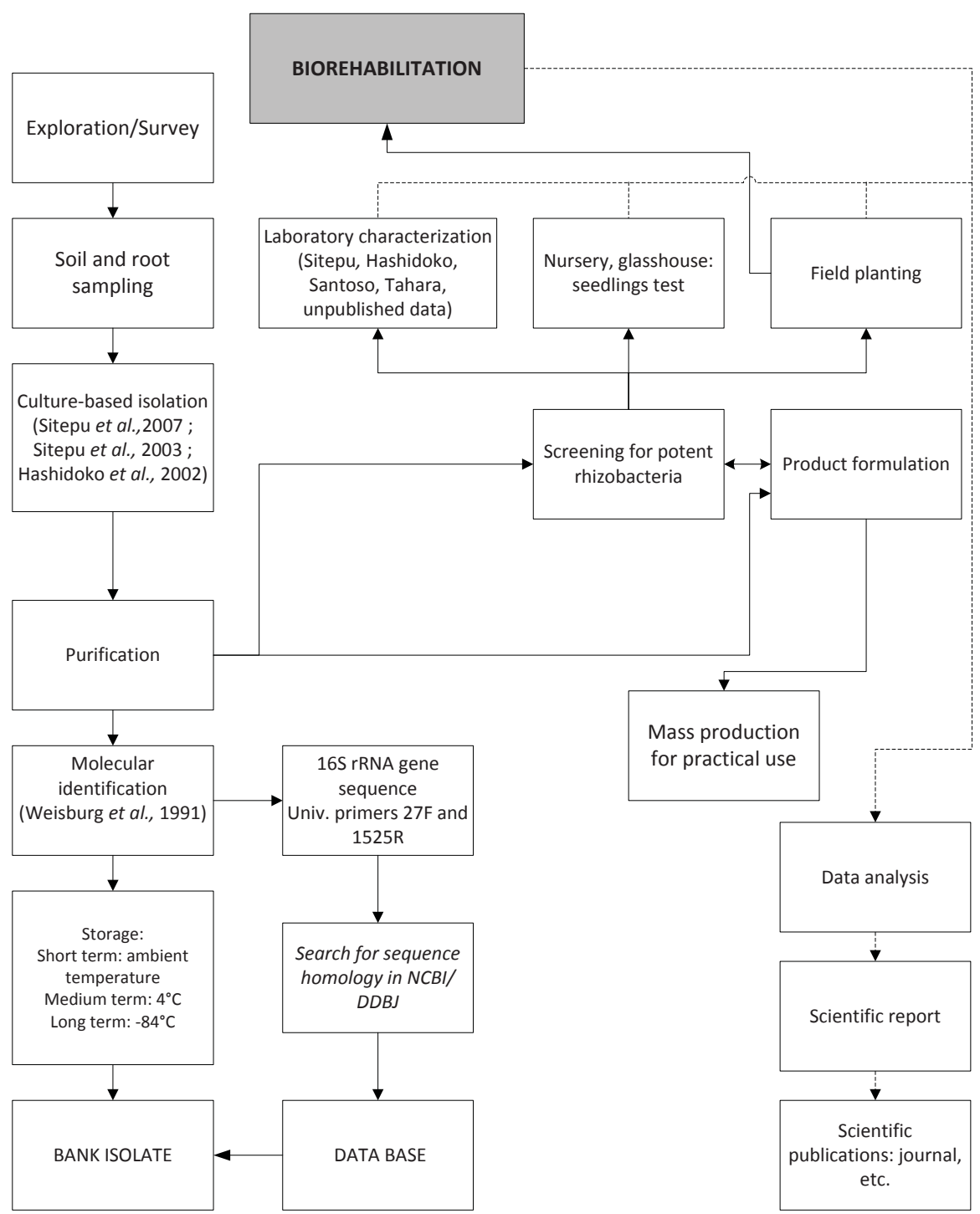

Figure 1. Orderly strategy in investigating functional bacteria of Indonesian tropical forest plants for biorehabilitation of degraded lands. 


\section{B. Sampling Sites}

Exploration and isolation of functional bacteria have been done from biogeoclimatically different forest conditions ranging from abandoned/degraded to conserved ecosystems in Indonesia. The ecosystems ranged from adverse soils to conserved ecosystems: (1) former coal mining (Figure 2.a and b), cement mining, and degraded peat swamp forest (Figure 2.c and d) to represent degraded forest and adverse soils; (2) nursery to represent a controlled condition; (3) plantation forest of BKPH (Bagian Kesatuan Pemangkuan Hutan or forest management unit at regency level) Gunung Kencana to represent a monoculture/ oligoculture man-made system; (4) experimental forests of Carita, Haurbentes, and Cikole to represent maintained and diverse vegetation compositions; and (5) arboretum Nyaru Menteng to represent a conserved ecosystem.

(a)

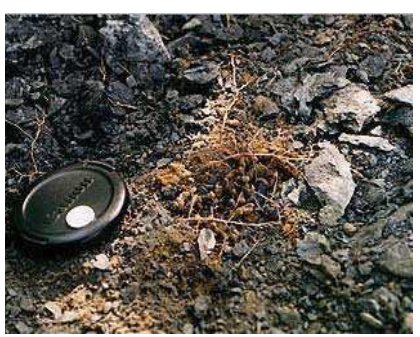

(c)

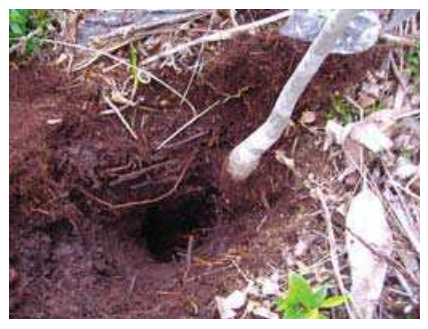

(b)

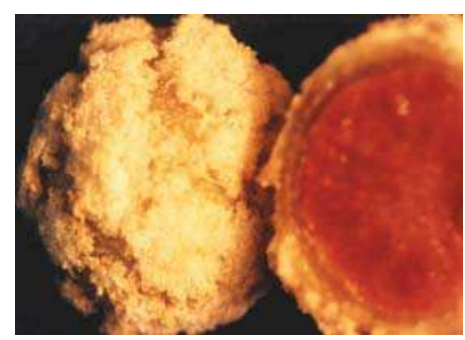

(d)

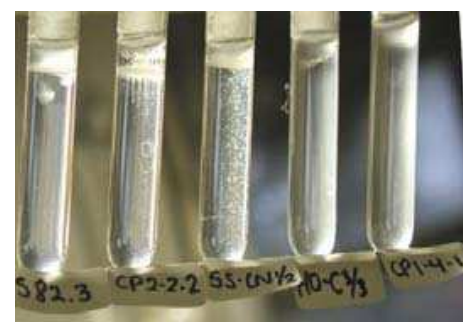

Figure 2. Orderly strategy in investigating functional bacteria of Indonesian tropical forest plants for biorehabilitation of degraded lands.

\section{RESULTS AND DISCUSSION}

\section{A. Isolation of Bacteria from Diverse Forest Conditions}

Using different types of media, 411 bacterial isolates were trapped from various forest plants grown in natural and pot conditions; and from various 
forests types in Sumatra, Java, and Kalimantan, Indonesia. A study by Singh et al. (2004) suggested that bacteria and plant are actually interdependent for nutrient supply. Plants select their bacterial partners based on their functions rather than taxonomic (Wieland et al., 2001). This may rationalize our findings of diverse genera of associative bacteria isolated regardless of tree species.

Bacterial identification showed that gram-negative bacteria predominantly isolated from host plants indicate the common nature of the plant rhizosphere (Table 1) Predominance of gram-negative bacteria in the rhizosphere has been previously reported by Olsson and Persson (1999) and Donata-Correa et al. (2004) who investigated rhizosphere bacteria of tagasaste and barley plants.

Table 1. Bacteria isolated from various forest types in Indonesia

\begin{tabular}{|c|c|c|c|c|c|}
\hline No. & $\begin{array}{c}\text { Total } \\
\text { Bacterial } \\
\text { isolates } \\
\end{array}$ & $\begin{array}{l}\text { Interaction with } \\
\text { host }\end{array}$ & $\begin{array}{l}\text { Isolation } \\
\text { media }\end{array}$ & Forest type & Provinces \\
\hline 1. & 14 & Association & WMM & $\begin{array}{l}\text { Lowland experimental forest, } \\
\text { Liamkiwa }\end{array}$ & $\begin{array}{l}\text { South } \\
\text { Kalimantan }\end{array}$ \\
\hline 2. & 82 & Association & WMM & $\begin{array}{l}\text { Lowland peatswamp } \\
\text { Dipterocarpaceae-dominated forest } \\
\text { maintained as arboretum in Nyaru } \\
\text { Menteng }\end{array}$ & $\begin{array}{l}\text { Central } \\
\text { Kalimantan }\end{array}$ \\
\hline 3. & 15 & Association & NA & $\begin{array}{l}\text { Lowland community peat swamp } \\
\text { forest }\end{array}$ & $\begin{array}{l}\text { West } \\
\text { Kalimantan }\end{array}$ \\
\hline 4. & 7 & Association & NA & $\begin{array}{l}\text { Lowland degraded peat swamp forest, } \\
\text { Kalampangan }\end{array}$ & $\begin{array}{l}\text { Central } \\
\text { Kalimantan }\end{array}$ \\
\hline 5. & 28 & Association & WMM & $\begin{array}{l}\text { Pongpok Landak Nursery of PT. } \\
\text { Perhutani/pot soil }\end{array}$ & West Java \\
\hline 6. & 29 & Association & WMM & Experimental forest Carita & Banten, Java \\
\hline 7. & 70 & Association & WMM & Nursery of FNCRDC* & West Java \\
\hline 8. & 11 & Association & WMM & Experimental forest Haurbentes & West Java \\
\hline 9 & 6 & Association & WMM & Nursery Hokkaido University ${ }^{* *}$ & Hokkaido \\
\hline 10. & 35 & Symbiotic & YMA & Upland experimental forest, Cikole & West Java \\
\hline 11. & 59 & Symbiotic & YMA & Former coal mining area, PTBA & South Sumatra \\
\hline 12. & 46 & Symbiotic & YMA & $\begin{array}{l}\text { Plantation forest of BKPH Gunung } \\
\text { Kencana, Perum Perhutani }\end{array}$ & Banten \\
\hline 13. & 9 & Symbiotic & YMA & $\begin{array}{l}\text { Upland adverse soil of former cement } \\
\text { mining, Cibadak }\end{array}$ & West Java \\
\hline
\end{tabular}

Note : WMM: Winogradsky's mineral mixture-based nitrogen-free medium solidified with $0.3 \%$ gellan gum; YMA: yeast mannitol agar, NA: nutrient agar; PDA: potato dextrose agar. $*$ : 4 strains were phylloplane bacteria; $* *$ : bacteria isolated from seedling rhizoplane of Indonesian origin. BKPH: Bagian Kesatuan Pemangkuan Hutan or forest management unit at regency level, PT Perhutani or state-owned forest enterprise; PTBA: Bukit Asam Mining Company; FNCRDC: Forest and Nature Conservation Research and Development Center. 
Isolated bacteria were maintained and stored in Forest Microbiology Laboratory, Forestry Research and Development Agency (FORDA), Indonesia and/or Ecological Chemistry Laboratory, Hokkaido University, Japan.

\section{B. Screening of Growth Acceleration Capacity by Symbiotic Bacteria on Seedlings in Glasshouse Condition}

Most rhizobia inoculated improved growth of $A$. crassicarpa seedlings in controlled condition in glasshouse (Figure 3; Data not shown). Rhizobia that accelerated height growth more than 100\% compared to non-inoculated seedlings are presented in Table 2. The most improved growth was achieved by seedlings inoculated with rhizobial strain S.8.4, as much as 254\% (Sitepu et al., 2003). Acacia crassicarpa is a legume species having better qualities and adaptabilities towards more diverse conditions compared with other acacias, such as $A$. mangium, $A$. auriculiformis, $A$. leptocarpa, $A$. aulocarpa, $A$. cincinnata, A. uraria and $A$. bylonola (various sources in Kapisa et al., 2000).

Effectiveness of symbiosis led to a better nitrogen fixation by rhizobial inoculant. Dowling and Broughton (1986) said that eventual growth performance of inoculated plants was a resultant of many factors including rhizobial genomic, plant genomic and environment. This study by Sitepu $e t$ al. (2003) allowed selections of the most prominent rhizobia for accelerating $A$. crassicarpa growth which is significant for nursery management from economical and ecological viewpoints.

(a)

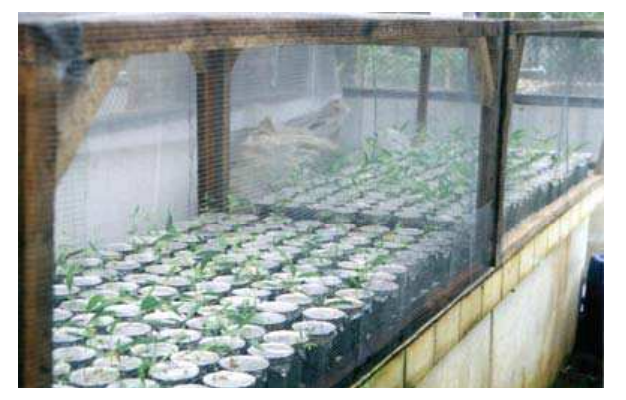

(b)

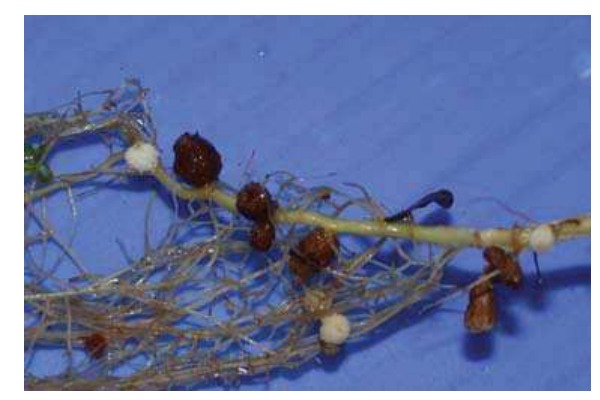

Figure 3. Screening of potent rhizobia for growth promotion of Acacia crassicarpa seedling. (a): simple screen house that protected $A$. crassicarpa seedlings from pest attack; (b): Symbiosis performed between inoculated rhizobia and $A$. crassicarpa as indicated by nodules. 
Table 2. Symbiotic bacteria isolated from post coal mining areas and their efficiency in improving growth of Acacia crassicarpa seedlings

\begin{tabular}{cclccc}
\hline No. & $\begin{array}{c}\text { Bacterial } \\
\text { isolates }\end{array}$ & Source of isolation & $\begin{array}{c}\text { Tested } \\
\text { host }\end{array}$ & $\begin{array}{c}\text { Symbotic } \\
\text { performance (\%) }\end{array}$ & $\begin{array}{c}\text { Height growth } \\
\text { acceleration (\%) }\end{array}$ \\
\hline 1 & S6.2 & Paraserianthes falcataria & Acacia & 42.27 & 107.46 \\
2 & S6.4 & Paraserianthes falcataria & crassicarpa & 72.07 & 183.22 \\
3 & S7.3.2 & Acacia auriculiformis & & 53.30 & 135.51 \\
4 & S8.4 & Paraserianthes falcataria & 100.0 & 254.21 \\
5 & S9.2 & Acacia mangium & 45.55 & 115.80 \\
6 & S10.3.1 & Acacia mangium & 56.50 & 143.64 \\
7 & S11.2 & Acacia mangium & 55.28 & 140.52 \\
8 & S22.1 & Acacia mangium & & 42.84 & 108.90 \\
9 & S34.1 & Acacia auriculiformis & 52.43 & 133.28 \\
10 & S38.2 & Acacia mangium & & 45.16 & 114.80 \\
\hline
\end{tabular}

\section{Screening of Growth Acceleration Capacity by Rhizobacteria on Seedlings in Glasshouse Conditions}

Bacteria have given immediate effect on seedling growth since the first month after inoculation. Dipterocarp seedlings responded variably to bacterial inoculation and most of the inoculated seedlings showed growth promotion. The growth promotion reached up to $41.4 \%$ and the most prominent PGPR strains from these studies are presented in Table 3. Only few of the tested bacteria gave negative effect on seedling growth. It has been pointed out that the negative effect is often resulted from phytotoxin produced by these bacteria (Brown and Rovira, 1999).

Inoculations of PGPR to the dipterocarp seedlings showed significant effect on their height growth rather than their diameter. Their ability to grow taller than other seedlings will help the seedlings to survive in nature in a competition with other ground storey vegetation. Dipterocarp seedlings require moderate light intensity in the forest floor in natural conditions, but full exposure to such light will kill the seedlings. 
Table 3. Rhizobacteria and their efficiency in improving growth of dipterocarp seedlings

\begin{tabular}{cllll}
\hline No. & \multicolumn{1}{c}{ Bacterial isolates } & Source of isolation & Tested host & $\begin{array}{c}\text { Height growth } \\
\text { acceleration }(\%)\end{array}$ \\
\hline & & & & \\
1 & Erwinia sp. FL11.2.2 & Shorea leprosula & Shorea selanica & 35.57 \\
2 & Alcaligenaceae FL2.4.2 & Hopea mengarawan & Shorea selanica & 33.56 \\
3 & Burkholderia sp. FL3.5.1 & Hopea odorata & Shorea selanica & 19.46 \\
4 & Pseudomonas sp. FL41 & Shorea selanica & Shorea leprosula & 29.01 \\
5 & Burkholderia sp. FL44 & Hopea mengarawan & Shorea leprosula & 27.48 \\
6 & Rhizobium sp. FL5.1 & Hopea mengarawan & Shorea leprosula & 30.53 \\
7 & NI HM3 & Hopea mengarawan & Shorea selanica & 28.71 \\
8 & Sphingomonas sp. R5b & Shorea balangeran & Shorea selanica & 32.67 \\
9 & Sphingomonas sp. SB3 & Shorea balangeran & Shorea selanica & 40.59 \\
10 & Burkholderia sp. FL37 & Shorea selanica & Shorea selanica & 27.23 \\
11 & Enterobacter sp. FL13.2.1 & Shorea leprosula & Shorea leprosula & 31.60 \\
12 & Burkholderia sp. CK32 & Shorea balangeran & Shorea leprosula & 41.40 \\
13 & Burkholderia sp. JW6 & Shorea selanica & Shorea leprosula & 23.50 \\
14 & Azospirillum sp. JW13 & Shorea selanica & Shorea leprosula & 32.00 \\
15 & NI CK4 & Shorea balangeran & Shorea leprosula & 30.70 \\
& & & & \\
\hline
\end{tabular}

\section{Screening of Growth Acceleration Capacity by Double Inoculation of Rhizobacteria and Arbuscular Mycorrhizal Fungi in Glasshouse Conditions}

Double inoculations of arbuscular mycorrhizal fungi (AMF) accelerated height and diameter growth of Alstonia scholaris seedlings up to 79 and 20.8\%, respectively compared to non-inoculated seedlings (Table 4). Our studies suggested that individual inoculation of either AMF or bacteria gave most significant effect on height growth, whereas double inoculation gave most significant effect on diameter growth (Data not shown).

Table 4. Double inoculation of bacteria and AMF and growth acceleration on Alstonia scholaris

\begin{tabular}{|c|c|c|c|c|}
\hline \multirow[t]{2}{*}{ Source of isolation } & \multirow{2}{*}{$\begin{array}{l}\text { Inoculant strains } \\
\text { (AMF + Bacteria) }\end{array}$} & \multirow[t]{2}{*}{ Tested host } & \multicolumn{2}{|c|}{$\begin{array}{c}\text { Growth acceleration } \\
(\%)\end{array}$} \\
\hline & & & Height & Diameter \\
\hline- & Non-inoculated & Alstonia & 0.00 & 0.00 \\
\hline Shorea selanica & Gigaspora sp.+ Burkholderia sp. JW6 & scholaris & 79.0 & 20.8 \\
\hline $\begin{array}{l}\text { Combretocarpus } \\
\text { rotundatus }\end{array}$ & Glomus sp. + NI Cr.R1.2 & & 77.1 & 14.5 \\
\hline Shorea selanica & Glomus sp. + NI JW3a & & 60.0 & 15.9 \\
\hline
\end{tabular}


Double inoculation of AMF and rhizobacteria increased $\mathrm{N}$ and $\mathrm{P}$ content of Agathis lorantifolia seedlings 6.5 months after inoculation (Figure 4; Miftahuliyah, 2006 unpublished data). The results showed that inoculations regardless of composition of AMF and/or bacteria gave a better nutrient content to the host plants. The most improved $\mathrm{N}$ and $\mathrm{P}$ contents $(12.8$ and $2.08 \mathrm{mg} /$ plant) were achieved by the seedlings inoculated with a combination of Gigaspora sp. and bacteria strain Aa.R2.1. On the other hand, N and P content of non inoculated seedlings were significantly lower than those of all inoculated seedlings by 10.8 and $0.31 \mathrm{mg} /$ plant, respectively. A better nutrient content indicated that microbes were functional even in a limited growth space such as polybag. Mycorrhizal fungi assisted $\mathrm{N}$ and $\mathrm{P}$ uptake of the plant roots (Smith et al., 1986). Several studies have demonstrated the beneficial effect of combined inoculations, for example, dual inoculations of plant growthpromoting rhizobacteria (PGPR) together with ectomycorrhizal fungus for optimum growth of seedlings (Frey-Klett et al., 1999). Garbaye (1994) suggested mechanism by which mycorrhization helper bacteria (MHB) may promote mycorrhization including stimulation and facilitating of the fungal growth and mycorrhizal establishment, initiation of root-fungus affinity, as well as receptivity of the roots for fungal infection. 
(a)

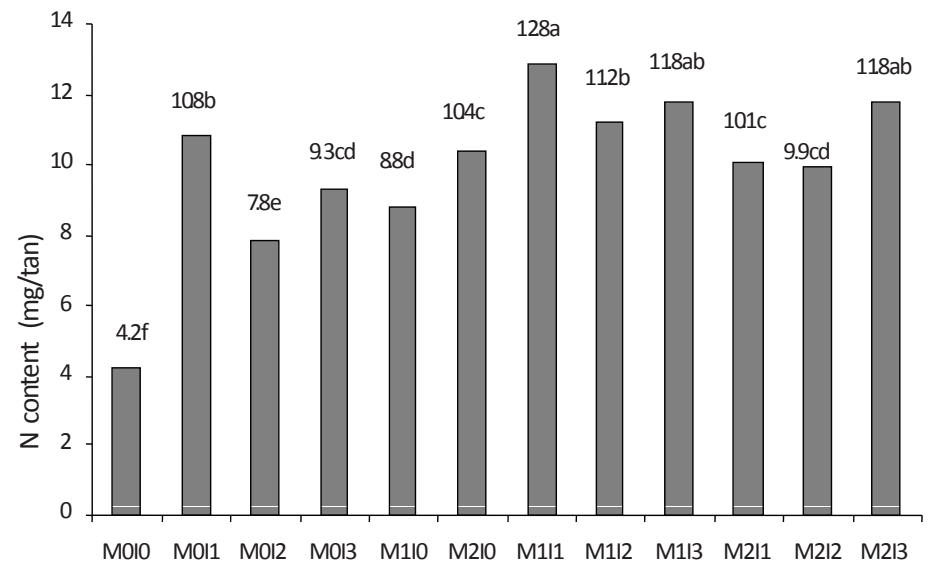

(b)

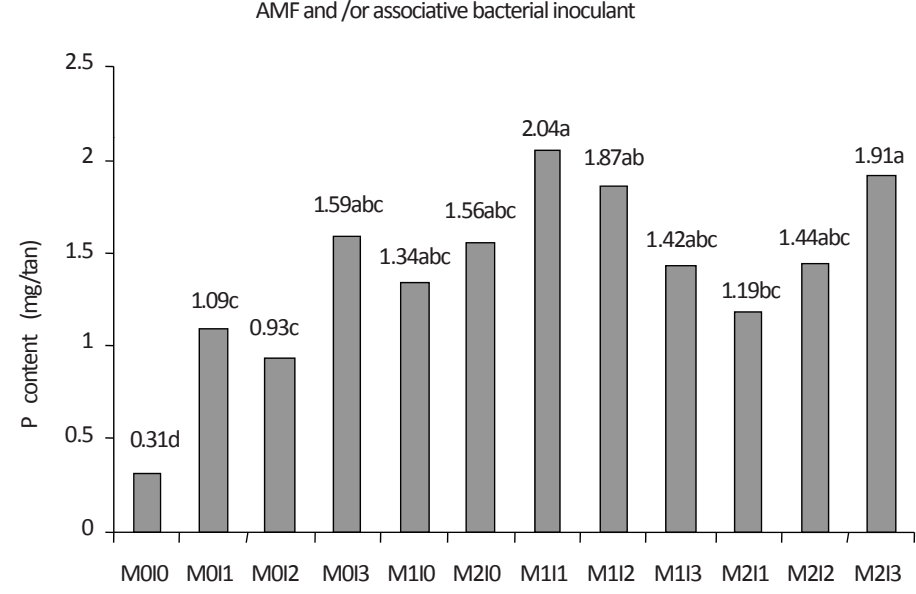

AMF and/or associative bacterial inoculant

Figure 4. $\mathrm{N}$ and $\mathrm{P}$ content of Agathis loranthifolia seedlings inoculated with AMF and rhizobacteria (Miftahuliyah et al., 2006 unpublished data). Note: MOIO (non-inoculated); MOI1 (without AMF + bacteria strain Aa.R2.1); MOI2 (without AMF + bacteria strain Gr.R2.1); MOI3 (without AMF + bacteria strain Nt.R2.2); M1IO (Gigaspora sp + without bacteria); M2I0 (Glomus clarum + without bacteria); M1I1 (Gigaspora sp + bacteria strain Aa.R2.1); M1I2 (Gigaspora sp + bacteria strain Gr.R2.1); M1I3 (Gigaspora sp + bacteria strain Nt.R2.2); M2I1 (Glomus clarum + bacteria strain Aa.R2.1); M2I2 (Glomus clarum + bacteria strain Gr.R2.1); M2I3 (Glomus clarum + bacteria strain Nt.R2.2). 


\section{E. What is necessary in bioreforestation using functional bacteria}

Our screening works in laboratory and glasshouse/nursery provide preliminary, which is yet an important information on the effective PGPR. Most bacteria induced growth promotion effect on tested plants. We have found that growth performance of plants after inoculation is a resultant of bacteria-host-environment interaction. The consequence of this interaction is a rather specific case therefore screening work should not be overlooked for obtaining optimum growth promotion effect. In a relatively small pot condition, however, particularly at the initial stage, competition is likely so high for nutrition, water as well as niche. It is clear that much more complex mechanisms are on functioning in the bacteria-plant interaction than what we have already understood.

In the case of legume-rhizobia symbiosis, Kijne (1992) reported the rate of biological fixation from this symbiosis that reached $40 \%$ of the global fixation rate or approximately 70 tons of available nitrogen per year. The author further suggested that this type of symbiosis could provide exclusive nitrogen supply available for plant uptake and replace the use of urea fertilizer. Although these studies have been done extensively, particularly in the agriculture sector, Brockwell et al. (1995) and Thies et al. (1992) reported that an introduction of foreign rhizobial inoculant to a new soil environment often failed to conduct efficient symbiosis due to a severe competition with the native rhizobia and other soil inhabitants. Therefore, searching for local biopotential of rhizobia from each of the targeted sites for biorehabilitation should be implicated.

Utilization of PGPR in agriculture is different from that in forestry because of the different practices in these two research disciplines. In agriculture, rhizobacteria are commonly applied as bacterial paste coated on annual crop seeds, and the seeds are directly planted in the fields; but in the forestry, rhizobacteria are often applied to perennial seedlings firstly grown in nursery before transplanting to the fields (Lucy et al., 2004). Application of these functional bacteria isolated from various forest types in Indonesia for preparation of seedlings in the nursery is one alternative to obtain ecological and economical benefits. This approach would be more preferable than the excessive inputs of inorganic fertilizers, such as of NPK fertilizers. Nowadays, the urge to find alternative to reduce environmental loads due to chemicals utilization have widely drawn attentions. Kloepper (2003) raised the problem of nitrate contamination of ground water and phosphate run-off that has led to eutrophication of ponds and rivers.

Seedlings usually suffer low survival rate after the transplanting into adverse soils. Inoculated seedlings by PGPR (including rhizobia) or consortium inoculant would lead to increase of the survival rate after the transplanting 
into the fields. A further study to test the preliminary nursery results will be implicated in our future works. In the adoption process of the seedlings to adverse environments in a complex and natural situation, more important and interesting nature of PGPR-plant interaction may be discovered.

From a practical viewpoint, biorehabilitation is dependent upon soil managements by providing sufficient nutrient for plants to grow well. It is then necessary to focus on rhizosphere soil because PGPR have abilities to alter and regulate such micro-scale of soil environments. These studies would provide a better understanding in planning a practical biorehabilitation strategy.

Preparation of seedling inoculated with bacteria before the outplanting is relatively easy for nursery application, environmentally benign, and inexpensive. The use of indigenous plant species over introduction of exotic ones is another important consideration for bioreforestation. Local trees are more adaptable to site local condition and their timber and non-timber productions are highly saleable and priceless. In a global account, regenerated forest may contribute to responding to the current global issues of carbon sink destruction as well as greenhouse emission that accelerate global warming and exacerbate El Nino weather impact.

\section{CONCLUSIONS}

1. Four hundreds and eleven bacteria isolates were trapped from diverse hosts of various forest conditions in Indonesia including degraded, nursery, manmade, experimental, and conserved forests.

2. Various responses of seedlings due to inoculations form our repeated studies which emphasized the importance of screenings stage of rhizobacteria for optimum growth improvement. Inoculations gave positive, no or negative effect on seedling growth.

3. Bacteria functioned immediately after inoculation, promoting various growth performances of the tested seedlings. This stage is very critical in screening effective rhizobacteria and understanding the ecological role of these bacteria in their interaction with trees.

4. Double inoculation of rhizobacteria and AMF increased $\mathrm{N}$ and $\mathrm{P}$ content of Agathis lorantifolia seedlings 6.5 months after inoculation. The most improved $\mathrm{N}$ and $\mathrm{P}$ contents (12.8 and $2.08 \mathrm{mg} / \mathrm{plant}$ ) were achieved by the seedlings inoculated with a combination of bacteria strain Aa.R2.1 and Gigaspora sp.

5. Biorehabilitation of adverse soils is dependent upon soil managements, and it is necessary to focus on rhizosphere because PGPR have abilities to alter and regulate rhizosphere. Our understanding of such micro- 
scale environment would assist us in formulating a practical strategy for biorehabilitation.

\section{ACKNOWLEDGEMENT}

The studies were financially supported by various funding sources including APBN, MOF from 2001-2007; 2003 RITE project to Y.H.; JSPS no. 16208032 grant-in-aid to Y.H.; Monbukagakusho and JSPS-LIPI Core University Program on Environmental Conservation and Land-use Management of Wetland Ecosystem in Southeast Asia. Najmullah, Sugeng Santosa and Ahmad Yani are appreciated for their sincere laboratory and glasshouse assistance.

\section{REFERENCES}

Brockwell J., P. J. Bottomley, and J. E. Thies. 1995. Manipulation of rhizobia microflora for improving legume productivity and soil fertility: A critical assessment. Plant and Soil 174: 143-180.

Brown, G.D. and A.D. Rovira. 1999. The rhizosphere and its management to improve plant growth. Advances in Agronomy 66: 1-102.

Chanway, C.P. 1997. Inoculation of tree roots with plant growth promoting soil bacteria: an emerging technology for reforestation. Forest Science 43: 99-112.

Donate-Correa, J., M. Le' on-Barrios, and R.P'erez-Galdona. 2004. Screening for plant growth-promoting rhizobacteria in Chamaecytisus proliferus (tagasaste), a forage tree-shrub legume endemic to the Canary Islands. Plant and Soil 266: 261-272.

Dowling D. N. and W. J. Broughton. 1986 Competition for nodulation of legumes. Annual Reviews of Microbiology 40: 131-157.

Frey-Klett, P., J.C. Pierrat, and J. Garbaye. 1999. Location and survival of Mycorrhiza helper Pseudomonas fluorescens during establishment of ectomycorrhizal symbiosis between Laccaria bicolour and Douglas fir. Applied and Environmental Microbiology 63: 139-144.

Garbaye, J. 1994. Helper bacteria: a new dimension to the mycorrhizal symbiosis. New Phytolology 128: 197-210.

García, J.A., J. Domenech, C. Santamaria, M. Camacho, A. Daza, and F.J.G. Maňero, 2004. Growth of forest plants (pine and holm-oak) inoculated with rhizobacteria: relationship with microbial community structure and biological activity of its atmosphere. Environmental and Experimental Botany 52: 239-251. 
Journal of Forestry Research Vol. 5 No. 1, 2008: 21 - 35

Hashidoko, Y., M. Tada, M. Osaki, and S. Tahara. 2002. Soft gel medium solidified with gellan gum form preliminary screening for root-associating free-living bacteria inhabiting the rhizoplane of plants. Bioscience Biotechnology Biochemistry 66: 2259-2263.

Kloepper, J.W. 2003. A review of mechanisms for plant growth promotion by PGPR. $6^{\text {th }}$ International PGPR Workshop, 5-10 October 2003, Calicut, India. WWW: http://www.ag.auburn.edu/ mlowens/india/ october2003/Contents.pdf

Kapisa, N., Jayusman and R. Harahap. 2000. Growth of bank clone Acacia crassicarpa 1 year after planting. Buletin Penelitian Kehutanan 15:1-9.

Kijne, J.W. 1992. (G. Stacey, R.H. Burris and H.J. Evans, Eds). The Rhizobium infection process. In Biological Nitrogen Fixation. Chapman and Hall, New York. pp. 349-398.

Lucy, M., E. Reed, and B.R. Glick. 2004. Application of free living plant growthpromoting rhizobacteria. Anthony van Leuwenhoek 86:1-25.

Miftahuliyah, S.S. 2006. Double inoculation of arbuscular mycorrhizal fungi and free-living bacteria on the growth of Agathis loranthifolia Salibs. Undergraduate thesis. Winayamukti University, Bandung, Indonesia.

Olsson, S. and P. Persson. 1999. The composition of bacterial populations in soil fractions differing in their degree of adherence to barley roots. Applied Soil Ecology 12: 205-215.

Sitepu, I.R., E. Santoso, and U. Muflih. 2003. Effectivity of rhizobia isolated from marginal acid land ex-coal mining in accelerating Acacia crassicarpa seedling growth. Proceedings of Research and Development Discussion "Forest Resource Rehabilitation and Conservation". Bogor, 23 December 2002. in Indonesian language.

Smith, A., S.E. Smith, B.J. John, and D.J.D. Nicholas. 1986. Inflow of $\mathrm{N}$ and P Into roots of mycorrhizal and non-mycorrhizal onions. Physiological and Genetical Aspects of Mycorrhizae. Proceedings of $1^{\text {St }}$ International European Symposium on Myccorrhizae, Dijon, 1-5 July 1985. INRA: 371-376.

Singh, B.K., P. Millard, A.S. Whiteley, and J.C. Murrell. 2004. Unraveling rhizosphere-microbial interactions: opportunities and limitations. Trends in Microbiology 12: 386-393.

Subiakto, A., C. Sakai, S. Purnomo, and Taufiqurahman. 2005. Cutting propagation as an alternative technique for mass production of dipterocarps planting stocks in Indonesia. $8^{\text {th }}$ Round Table Conference on Dipterocarps, 
HCMC, Vietnam, 15-17 November, 2005. APAFRI. Ho Chi Minh City, Vietnam.

Thies J.E., B.B. Bohlool, and P.W. Singleton. 1992. Environmental effects on competition for nodule occupancy between introduced and indigenous rhizobia and among introduced strains. Canadian Journal of Microbiology 38: 493-500.

Tilak., K. V. B. R., N. Ranganayaki, K.K. Pal, R. De, A. K. Saxena, C.S. Nautiyal, S. Mittal, A.K. Tripathi, and B.N. Johri. 2005. Diversity of plant growth and soil health supporting bacteria. Current Science 89: 136-150.

Wieland G., R. Neumann, and H. Backhaus. 2001. Variation of microbial communities in soil, rhizosphere, and rhizoplane in response to crop species, soil type, and crop development. Applied and Environmental Microbiology 67: 5849-5854. 
